\title{
An Evaluation of Special Economic Zones (SEZs) Performance Post SEZs Act 2005
}

\author{
Abdul Rahoof TK*, P. G. Arul \\ Department of International Business, Pondicherry University, India
}

Copyright $(2016$ by authors, all rights reserved. Authors agree that this article remains permanently open access under the terms of the Creative Commons Attribution License 4.0 International License

\begin{abstract}
Special Economic Zones (SEZs) has been the growth engine of many developing countries around the world for the last few decades. The SEZ Scheme was introduced to provide a special area to expertise in international trade by providing an attractive fiscal package both in central and state government level with little regulations. SEZs have made Indian economy compatible with the global economy. The SEZ Act 2005 was passed with a view to increase the pace of economic growth. So far the Government of India (GOI) has given formal approval to 491 SEZs in which 199 SEZs already started exporting, out of which majority are from IT/ITES, pharmaceuticals and chemical sectors. GOI came forward with a lot of incentives for attracting investors to the scheme. The newly elected NDA government is seriously looking for the development of SEZs. The performance of Indian SEZs in the post-SEZ Act era has been gaining attention; it shows a tremendous increase in export, investment and employment. This paper is an attempt to study the performance of SEZ in India and its impact on India's export, investment and employment. In addition to this, the recent government initiatives in terms of privileges, tax exemptions, rebates, policy initiatives to improve the performance of SEZ are also addressed in this paper. For the extensive analysis of this study, data were collected from the Ministry of Commerce and Industry, Ministry of Finance, Reserve Bank of India and from various websites and newspapers.
\end{abstract}

Keywords Special Economic Zones (SEZs), Export Processing Zones (EPZs), SEZ Act 2005, Export, Investment, Employment and Tax Incentives

\section{Introduction}

Free Trade Zones is not a new phenomenon; different countries started implementing the concept of free trade zones three centuries ago. Gibraltar (1704), Singapore (1819), China (1848), Hamburg (1888) and Copenhagen (1891) are the countries which make use of special zones to strengthen economic development (World Bank, 2008) [22]. India was one of the first countries in Asia to start the concept of special zones by setting up Export Processing Zone (EPZ) in Kandla in 1965. Another six export processing zones were also set up in different parts of the country during 90's. EPZ Scheme was not successful in the Indian perspective as it was in other developing countries like China, Taiwan, Singapore, etc. Indian government followed the EPZ scheme as a basis to provide incentives to increase export. There were no committed policy initiatives towards this scheme like other developing countries had (Aradhana Aggarwal 2012)[2]. The EPZs was a failure because of unwanted control, complex clearance process and lack of better infrastructural setup. The SEZ policy was announced in 2000 by the Government of India (GOI) with a view to overcome the shortcomings of the EPZ scheme. The SEZs policy was announced with a view to make SEZs as an engine of economic growth by attracting foreign as well as domestic investment, to generate additional employment, boost up country's export and to facilitate infrastructural development. SEZs enhances human development through employment generation, skill formation and technology and knowledge upgradation (Aradhana Aggarwal 2007)[3]. SEZs are special areas with better infrastructural facilities and attractive incentive packages, and which is considered as a foreign territory for the purpose of trade. SEZs are eligible to import duty free raw materials and capital goods required for production. A comprehensive Special Economic Zones Act was passed by the GOI in 2005 to strengthen the SEZ Scheme in India. The SEZs Act 2005 came into effect on February 2006 supported by SEZ Policy 2000. The main aim of the Act was to simplify the business procedures and thereby attract more investors to the country. Through SEZ Act anyone could apply for setting up of SEZs in the country which previously was more complex as most of SEZs were owned either by central or state government.

\section{Special Economic Zones in India}

The new initiatives such as Make in India, Skill India and Digital India were introduced by the present NDA government to facilitate the ease of doing businesses in the country. The Special Economic Zones has made Indian economy compatible with other global economies like China, 
UK, Japan, and USA. Kandla EPZ (1965) was first converted into Special Economic Zone followed by six other central government EPZs (Santacruz Electronics EPZ, 1973, Noida SEZ 1976, Madras EPZ, Cochin SEZ, Falta SEZ, 1984, and Vishakapattanam SEZ 1989) during the year 2000. After the SEZ Policy 2000, 11 more SEZs were established by different state governments and private sectors in different parts of the country (West Bengal (2), Tamil Nadu (4), Madhya Pradesh (1), Uttar Pradesh (1), Gujarat (1), and Rajasthan (2). Since the SEZ Act came into effect in 2006 there has been a tremendous increase in the number of SEZs across the country especially in IT/ITES, Pharmaceutical and Chemical sectors. Till now the GOI has given formal approval for 491 SEZs, of which 352 are notified. As of December 2014, 199 SEZs have already started exporting, which includes 7 central government SEZs, 11 state government/private sector SEZs established prior to 2005 and 181 SEZs notified under SEZ Act 2005. Though most of SEZs are concentrated in the states of Andhra Pradesh, Maharashtra, Tamil Nadu, Karnataka and Kerala it has spread over 20 states and 3 union territories. The total land capacity used for development and operation of SEZs in the country is around 56066.69 hectares, which accounts only $0.017 \%$ of the total land area of the country. Presently land acquisition and displacements are the acute problems faced by the SEZs developers and the GOI. Recently the GOI has reduced the minimum land requirements for establishing SEZs, which will help to curb the land acquisition problem to an extent. Also this will help the investors to establish more number of multi product SEZs in the near future. As far as the notified SEZ (which are not operational) are concerned, the required land has been acquired already and these SEZs are going to be a big opportunity for the government's 'Make in India' policy. The GOI is losing a good amount of money for developing and promoting the scheme, for the year 2013-14 a sum of Rs. 25071 crores has been forgone under different schemes, i.e. exemption on corporate profit of units in SEZs and units engaged in development of SEZs and by way of different export promotional concessions. The estimated revenue loss to the government for the year 2014-15 comes around Rs. 25909 crores. Imposition of Minimum Alternate Tax (MAT) and Dividend Distribution Tax (DDT), absence of complementary infrastructure and land acquisition are the main factors which pull back the growth of SEZs in India in recent years (Business Standard, $4^{\text {th }}$ December 2014)[10]. Several SEZs licenses were surrendered after imposing MAT and DDT.

Though many benefits come through SEZs like foreign exchange, employment and investment there are also a lot of pitfalls. Compulsory land acquisition and displacement are the main drawbacks of the scheme. Most of the lands acquired compulsorily by the government are farm lands of poor people and also the compensation given to them is very less compared to the market price of land. This creates loss of livelihood of the poor people and they are compelled to move to other places. The estimates show that at least 10 lakh people who depend upon agriculture for their survival will face eviction (Citizens research collective, New Delhi). The usage of farm land acquired forcibly for some other purposes will create food crisis in coming future. The government can use the lands which are not used for agricultural purposes for the establishment and development of SEZs and it can curb the land acquisition and displacement problem to an extent.

The following table. 1 shows the state wise distribution of SEZs in India.

Table 1. State wise distribution of SEZs in India as on December 2014

\begin{tabular}{|c|c|c|c|c|}
\hline State & Formal Approvals & In-principle approvals & Notified SEZs & Exporting SEZs \\
\hline Andhra Pradesh & 40 & 4 & 30 & 19 \\
\hline Chandigarh & 2 & 0 & 2 & 2 \\
\hline Chhattisgarh & 2 & 1 & 1 & 1 \\
\hline Delhi & 3 & 0 & 0 & 0 \\
\hline Goa & 7 & 0 & 3 & 0 \\
\hline Gujarat & 35 & 4 & 28 & 18 \\
\hline Haryana & 34 & 3 & 25 & 6 \\
\hline Jharkhand & 1 & 0 & 1 & 0 \\
\hline Karnataka & 59 & 0 & 39 & 25 \\
\hline Kerala & 32 & 0 & 25 & 14 \\
\hline Madhya Pradesh & 19 & 1 & 9 & 2 \\
\hline Maharashtra & 69 & 9 & 52 & 25 \\
\hline Manipur & 1 & 0 & 1 & 0 \\
\hline Nagaland & 2 & 0 & 2 & 0 \\
\hline Orissa & 8 & 1 & 4 & 2 \\
\hline Puducherry & 1 & 1 & 0 & 0 \\
\hline Punjab & 8 & 0 & 2 & 2 \\
\hline Rajasthan & 9 & 1 & 8 & 4 \\
\hline Tamil Nadu & 55 & 4 & 51 & 36 \\
\hline Telangana & 60 & 0 & 42 & 25 \\
\hline Uttar Pradesh & 31 & 1 & 22 & 11 \\
\hline Uttarakhand & 1 & 0 & 0 & 0 \\
\hline West Bengal & 12 & 2 & 5 & 7 \\
\hline GRAND TOTAL & 491 & 32 & 352 & 199 \\
\hline
\end{tabular}

Source: Annual Report 2014-15, Department of Commerce, Ministry of Commerce and Industry, Government of India. 


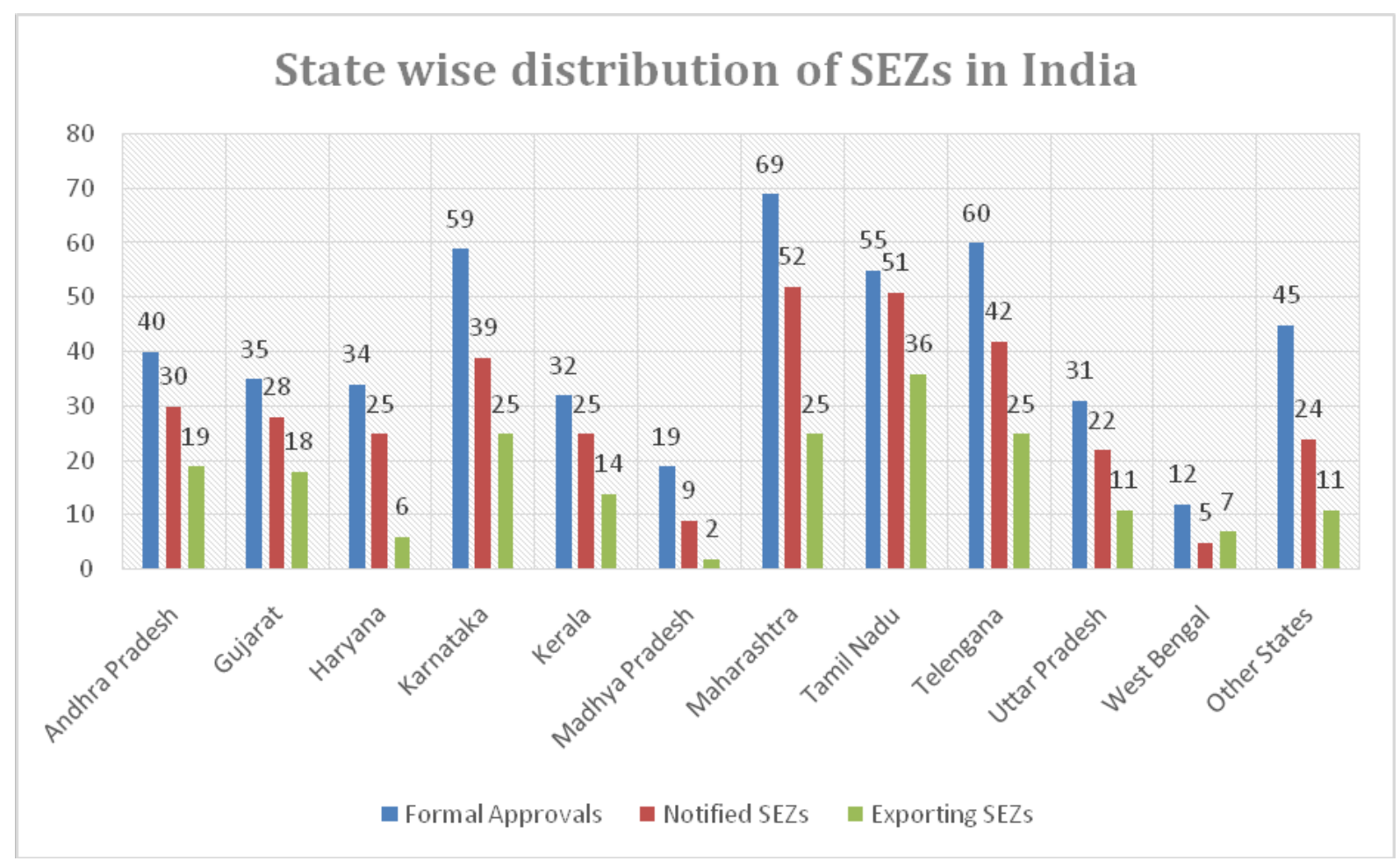

Source: Annual Report 2014-15, Department of Commerce, Ministry of Commerce and Industry, Government of India.

Figure 1. State wise distribution of SEZs in India as on December 2014

The latest figures from The Ministry of Commerce and Industry (MoCI) show that most of the Indian SEZs are concentrated in very few states. As of December 2014 around $85 \%$ of formally approved SEZs are located in 9 states alone, that is in the states of Andhra Pradesh, Karnataka, Tamil Nadu, Gujarat, Haryana, Maharashtra, Kerala, Telengana and Uttar Pradesh. A sum of 179 exporting SEZs are lying in these 9 states out of the 199 exporting SEZs. Latest figures show that 5 more SEZs have started its operation as on $30^{\text {th }}$ June 2015 . Further, as per the Commerce Ministry there are 225 non-operational SEZs in the country. The focus of SEZs in these specific states limits the scope of the scheme, i.e. employment generation, infrastructural development and balanced regional growth. The states with coastal areas are not fully utilizing the benefits available to them in the form of easy access to ports. According to Commerce and Industry Minister Nirmala Sitharaman, over 90 percentage of the land has been lying vacant of the area notified for setting up of 58 SEZs for the last five years throughout the country. Proper use of idle land can help enhance the productivity of SEZs and generate more employment.

\section{Sector Wise Distribution of SEZs in India}

The major sectors involved in the scheme are IT/ ITESs, hardware and electronics, engineering, pharmaceuticals/chemicals, multi-product, biotech, etc. These sectors alone account for more than $80 \%$ of the total formal approval granted so far. The fact is that about $71 \%$ formally approved SEZs are notified and more than $56 \%$ of them have started exporting. Major share of IT/ITES and Engineering shows the dominance of services sector in the scheme and it provides employment opportunities to skilled people than to unskilled. There are around 4000 units in different SEZs across the different sectors. The Comptroller and Auditor General of India (CAG) says that there is an imbalance in the growth of IT/ITES and manufacturing sectors in Indian SEZs. It also argued that manufacturing sector is discouraged by not offering much benefit. Since the employment generation and balanced growth are the major objectives of the SEZ scheme it cannot be achieved by focusing only on IT/ITES sectors. Due consideration on the manufacturing sector can generate more employment opportunities especially to semi-skilled and unskilled laborers and thereby improve the standard of living of the people around the SEZs. Manufacturing sectors are less encouraged by the government, so most of the SEZs developers are focused on service sectors. The 'Make in India' program initiated by the government recently is a best opportunity to establish more manufacturing SEZs in the country. The following diagram shows the sector wise distribution of exporting SEZs in the country. 


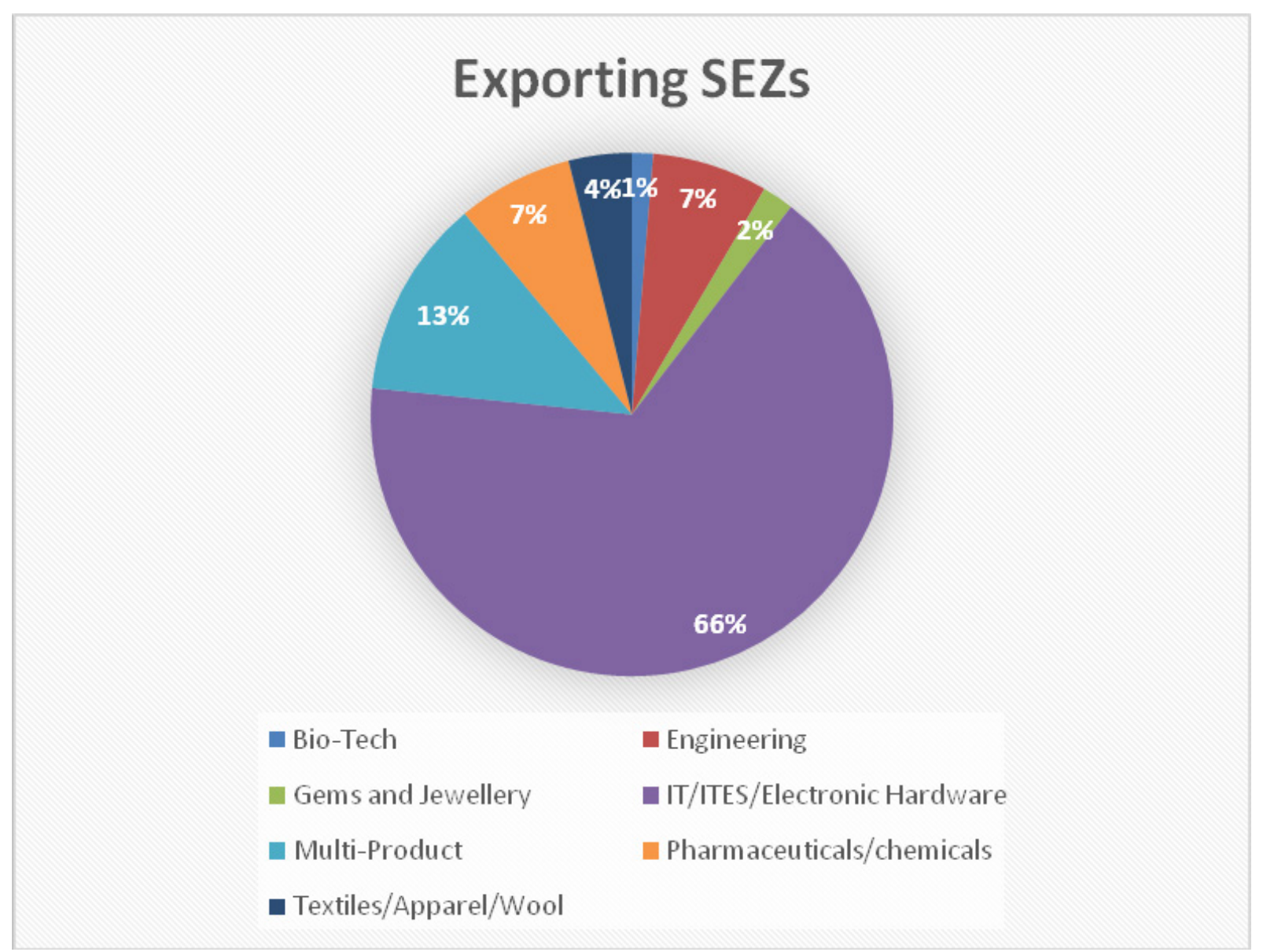

Source: Annual Report 2014-15, Department of Commerce, Ministry of Commerce and Industry, Government of India.

Figure 2. Sector wise Exporting SEZs as on December 2014

\section{Export Performance of SEZs in India after SEZ Act 2005}

International trade is the way an economy can acquire required foreign exchanges and enhance the pace of economic growth of the nation. Improving the growth of export of the nation is one of the prominent objectives of the SEZ scheme in India. SEZs in India varies over a number of sectors like IT/ITES, Electronics and Hardware, Textiles and apparels, Chemical and Pharmaceuticals, Gems and Jewelry and Engineering etc. As of June 2015, 204 notified SEZs have already started exporting their products and services. Most of them are from IT/ITES followed by electronics and hardware sectors. SEZs in India have witnessed a rapid increase in total production and export after the SEZ Act 2005 came into effect. Export from SEZs have rose from Rs. 22840 crores in the year 2005-06 to Rs.463000 crores in the year 2014-15, which means the export rose by around 2000 percentage during the short period of 9 years. The export performance of SEZs shows a major increase since the SEZ Act 2005 (Deepak Shah 2009)[7]. But for the last few years it has been showing lesser growth of export due to the withdrawal of benefits available to SEZs such as exemption on MAT and DDT. The table shows the export done from SEZs in India since SEZ Act 2005. 
Table 2. Export performance of SEZs in India

\begin{tabular}{|c|c|c|c|c|c|}
\hline Year & $\begin{array}{c}\text { SEZs Export } \\
\text { (Value Rupees in Crores) }\end{array}$ & $\begin{array}{c}\text { Percentage increase } \\
\text { in SEZs export }\end{array}$ & $\begin{array}{c}\text { India Export } \\
\text { (Value Rupees in Crores) }\end{array}$ & $\begin{array}{c}\text { Percentage increase } \\
\text { in India export }\end{array}$ & $\begin{array}{c}\text { Share of SEZs export } \\
\text { in Indian Export }\end{array}$ \\
\hline $2005-06$ & 22840 & & 456418 & & 5.00 \\
\hline $2006-07$ & 34615 & 51.6 & 571779 & 25.3 & 6.05 \\
\hline $2007-08$ & 66638 & 92.5 & 655864 & 14.7 & 10.16 \\
\hline $2008-09$ & 99689 & 49.6 & 840755 & 28.2 & 11.86 \\
\hline $2009-10$ & 220712 & 121.4 & 845534 & 0.6 & 26.10 \\
\hline $2010-11$ & 315868 & 43.1 & 1142922 & 35.2 & 27.64 \\
\hline $2011-12$ & 364478 & 15.4 & 1468959 & 28.5 & 24.81 \\
\hline $2012-13$ & 476159 & 30.6 & 1634318 & 11.3 & 29.14 \\
\hline $2013-14$ & 494077 & 3.8 & 1905011 & 16.6 & 25.94 \\
\hline $2014-15$ & 463000 & -6.3 & 1897026 & -0.4 & 24.41 \\
\hline
\end{tabular}

Source: Annual Report 2014-15, Department of Commerce, Ministry of Commerce and Industry, Government of India, Handbook of Statistics on Indian Economy, Reserve Bank of India.

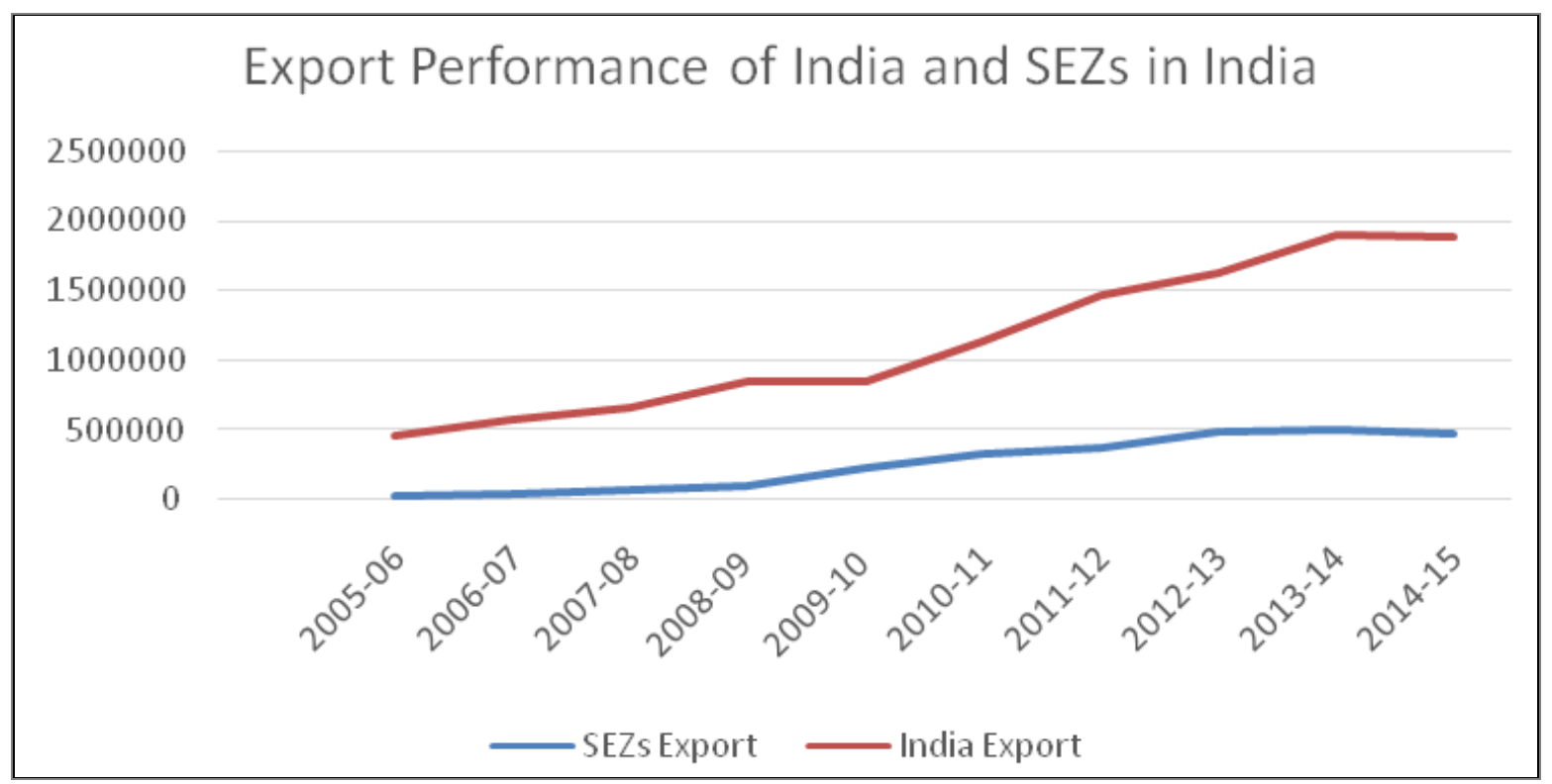

Source: Annual Report 2014-15, Department of Commerce, Ministry of Commerce and Industry, Government of India, and Handbook of Statistics on Indian Economy 2014-15, Reserve Bank of India.

Figure 3. Export performance from SEZs and India

Table 3. Average Annual Growth Rate of SEZs and India's Export

\begin{tabular}{|c|c|}
\hline \multicolumn{2}{|c|}{ Average Annual Growth Rate } \\
\hline SEZs export & India Export \\
\hline 225.24 & 46.18 \\
\hline
\end{tabular}

The average annual growth rate of the export from SEZs during the year 2005-06 to 2014-15 is 225.24 percent. Whereas the average annual growth rate of India's export for the same period is only 46.18 percent. It shows that units from Indian SEZ are performing much better than that of units outside the SEZs in terms of export growth.

The diagram shows that export performance of Special Economic Zones in India was increasing since the inception of SEZ Act 2005 irrespective of global economic conditions, mainly the great recession in 2008-09. Soon after SEZ Act 2005 the export performance shows a stagnant growth, that is up to 2008-09 and thereafter it shows a tremendous increase in the SEZs export. The growth rate of export for the year $2009-10$ had been $121 \%$ regardless of global economic slowdowns whereas at the same time the growth rate of India's overall export is only $0.6 \%$, which means that Indian SEZs already settled its routes in the fast growing global market. But the export performance is in declining trend for the last few months because of the lack of confidence from the part of investors due to imposition of DDT, MAT and proposal to withdraw direct tax benefit from the year April 2017. Investment in more number of SEZs in diversified sectors has resulted in higher export growth in recent years. The growth of export in the sectors like Pharmaceuticals and chemicals, gems and jewelry and IT/ITES and electronic hardware uplift the total export of SEZs since the SEZ Act 2005. The main aim of the NDA government, announced in the Foreign Trade Policy 2015-20 is to double the exports by 2020 by providing various incentives for the exporters and units in the SEZs.

SEZs in India contribute around 25 percent of India's overall foreign trade from the year 2009-10 till date. The contribution of SEZs in the pace of export growth of the 
nation is significant. It shows that the scope for SEZs in the country is broad and in turn increases the investment, employment generation and balanced regional development. Major share of SEZs export is coming from pharmaceutical and chemical sectors even though they are less in number. It is also clear that despite IT/ITES, electronics and engineering SEZs being more in number their export performance is not justifiable. Establishing SEZs and units in SEZs only for availing various benefits and incentives and also for making the business easier reduces the scope for the development of the economy. Export performance of units in engineering, textiles and garments sectors is also insignificant though the sectors have got higher number of formal approval.

\section{Investment and Employment in Special Economic Zones}

The main feature of SEZs in India is $100 \%$ FDI through automatic route in almost all sectors. SEZs in India are largely attracted by the domestic as well as foreign and NRI investors. Since the inception of SEZ Act 2005 there has been a constant increase in the overall investment across the sectors. Notified SEZs have already made an investment of Rs. 318446 crores till December 2014 and 1279131 people were employed. Private zones are better in performance and lesser expensive to establish than that of public zones (World Bank 2008)[22]. The SEZs provide jobs mostly to people around the area. Since the SEZs are spread all over the country it provides a better opportunity to the semi-skilled and unskilled to get jobs in nearby SEZs. The table reveals that the overall investment has rose from Rs. 108903 crores in the year 2008-09 to Rs. 318446 crores in the year 2014, reporting an increase by 192 percent during that period.

As of $30^{\text {th }}$ June 2014 , the contribution of newly notified SEZs in overall investment of SEZs in the country comes around $92 \%$ within a short span of 9 years. At the same time the contribution of investment by the SEZs established prior to SEZ Act 2005 is only 8\%. But recent policy measures taken by the Government of India takes off some benefits available to SEZs thereby reduce the attractiveness of the scheme. With regard to employment generation newly notified SEZs contributed around $78 \%$ of total employment generated till June 2014, which indicates that these SEZs have made a substantial contribution in overall investment and employment generation compared to SEZs established prior to SEZ Act 2005. Apart from these, the indirect employment created through these SEZs is also important, which proves that the scope of Indian SEZs is wide and in an expanding stage.

Table 4. Investment and Employment in Special Economic Zones in India

\begin{tabular}{|c|c|c|c|}
\hline Year & $\begin{array}{l}\text { Additional Investment in SEZs notified under } \\
\text { SEZ Act 2005. (Value Rupees in Crores) }\end{array}$ & $\begin{array}{l}\text { cumulative employment (central } \\
\text { govt. state govt. \& and private SEZ }\end{array}$ & $\begin{array}{l}\text { additional employment made during } \\
\text { the period after SEZ Act 2005 }\end{array}$ \\
\hline $31 / 03 / 2009$ & 108903 & 394442 & 259738 \\
\hline $31 / 12 / 2009$ & 124000 & 490000 & 154000 \\
\hline $31 / 12 / 2010$ & 195000 & 644000 & 171308 \\
\hline $30 / 09 / 2011$ & 231159 & 1019146 & 203838 \\
\hline $31 / 12 / 2012$ & 238990 & 1283309 & 264163 \\
\hline $20 / 06 / 2014$ & 296663 & 1413835 & 130526 \\
\hline $31 / 12 / 2014$ & 318446 & & 2 \\
\hline
\end{tabular}

Source: Various Annual Reports, Department of Commerce, Ministry of Commerce and Industry, Government of India. 


\section{Share of overall Investment in SEZs}

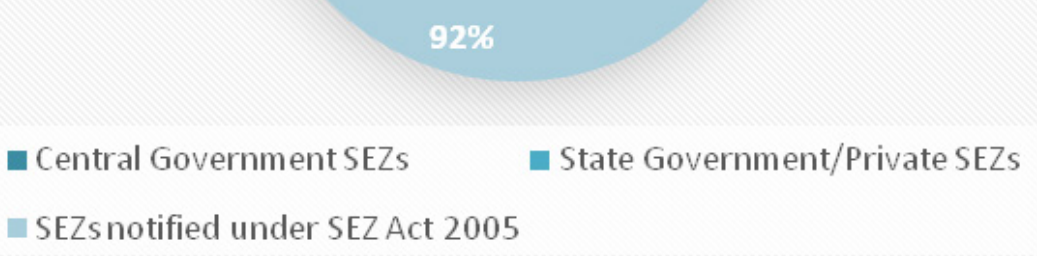

Source: Business Standard, December 4, 2014.

Figure 4. Proportion of overall investment as on $30^{\text {th }}$ June 2014

\section{Share of overall employment in SEZs}

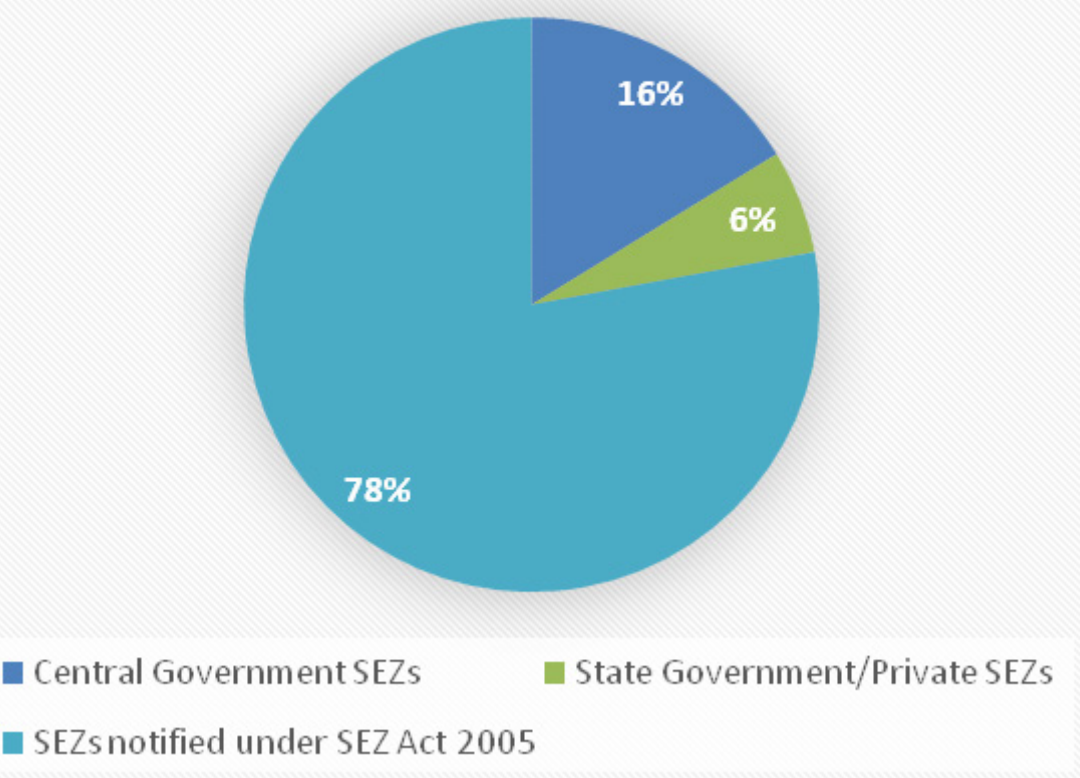

Source: Business Standard, December 4, 2014.

Figure 5. Proportion of overall employment as on $30^{\text {th }}$ June 2014

\section{Tax Concessions Offered to SEZ Units}

Exemptions are meant to reduce the tax burden of tax payers for encouraging them to invest in particular areas with disadvantageous condition, sector or project. Tax incentives and subsidies are very important for attracting units to the
Zones (Aradhana Aggarwal 2004)[5]. This is given for a positive impact from an investment such as transfer of technology, to achieve balanced regional development, infrastructural development, employment generation, increasing export, skill upgradation etc. At present, instead of firms competing with each other, the states are competing 
with each other to offer more incentives and benefits to attract firms to setup SEZs (Naresh Kumar Sharma 2009) [12]. Misuse of MAT and DDT by the SEZ business unit and SEZ developers compelled the government to withdraw the benefits from the year 2011-12. After that many units applied for de-notification because the DTA units are getting more benefits than the units in SEZs. The present NDA government focuses on cutting down the tariffs and MAT levied on the SEZ units that sell goods in the Domestic Tariff Area (DTA). At the same time the Union government is in the process of revising the chaotic exemptions and putting a "sunset clause" to the exemptions and benefits. But the experts say that this move will further reduce the attractiveness of SEZs and the government should go back from this. Since the government plans to take off some of the incentives and exemptions granted to SEZs units and SEZs developers gradually from the year 2011 the performance of SEZs in terms of exports and in total number of SEZs and SEZ units has come down drastically. As per the commerce ministry, imposition of MAT and DDT in the year 2011 led to the slowdown in the growth of SEZs in India. In addition to that the present government's plan to abolish the incentives to SEZs withdraws the attractiveness of the SEZs and a good number of SEZs have already surrendered their licenses to the government. From these it is clear that the continuation of the existing benefits and granting new benefits is very much essential for making all the SEZs operational which are already notified and also to make SEZs a more attractive destination for the success of the government's 'Make in India' program. The import taxes on small volumes of goods have been abolished and incentives have been introduced for Export Oriented Units (EOUs) and Export Processing Zone (EPZs) in the present Foreign Trade Policy 2015-2020 in support of Make in India initiatives. The table shows different concessions availed by the SEZ developers and SEZ units from the year 2006-07 to 2013-14.

Tax concessions offered to SEZs are justifiable as an aggregate when we consider the sectors that perform better. But there is always an ugly side, for the underperforming sectors granting benefits and incentives in different forms is simply loss of revenue to the government. Providing incentives and benefits to offset location and infrastructural disadvantageous SEZs will lead to poor performance by the zones (World Bank 2008)[22]. Not limiting the exemptions and deductions increases the revenue loss to the government; this doesn't bring desired level of output to the nation. So the government should make periodic review of all the benefits issued to SEZs and should get rid of unnecessary exemptions.

Table 5. Concessions availed by SEZs

(Value Rupees in Crores)

\begin{tabular}{|c|c|c|c|c|c|}
\hline \multirow{2}{*}{ Year } & \multirow{2}{*}{ Export exemptions } & \multicolumn{3}{|c|}{ Exemptions to SEZs } & \multirow{2}{*}{$\begin{array}{c}\text { Total exemption as a percentage of } \\
\text { export }\end{array}$} \\
\cline { 3 - 5 } & & corporate tax exemptions & Total \\
Exemptions & \\
\cline { 3 - 5 } & 2194 & SEZ Units & SEZ developers & 3018 & 8.72 \\
\hline $2006-07$ & 1804 & 1103 & 271 & 4757 & 7.14 \\
\hline $2007-08$ & 2324 & 2677 & 1850 & 6758 & 6.78 \\
\hline $2008-09$ & 3987 & 4233 & 1111 & 9331 & 4.23 \\
\hline $2009-10$ & 8630 & 7432 & 1326 & 17388 & 5.50 \\
\hline $2010-11$ & 4560 & 10916 & 1201 & 16677 & 4.57 \\
\hline $2011-12$ & 4491 & 13535 & 1531 & 19557 & 3.95 \\
\hline $2012-13$ & 6198 & 17036 & 1837 & 25071 & 5.07 \\
\hline $2013-14$ & 5532 & 18394 & 1983 & 25909 & \\
\hline $2014-15 *$ & & & & & \\
\hline
\end{tabular}

Source: Ministry of Commerce and Industry, Government of India.

*2014-15 figures are estimated figure by the Ministry of Finance, GOI. 


\section{Conclusions}

The new initiatives of present NDA government in the budget and ongoing discussions and efforts to boost up the SEZs in India gives hope to the investors. SEZ Act and the Indian government have made a well-established platform to the investors for the ease of doing their business activities. The growth of Indian SEZs with regard to investment, employment generation, export, regional development is outstanding since SEZ Act 2005 came into effect. Even though SEZs are concentrated in some specific states and sectors, it is spread all over the country and throughout many numbers of sectors. Regional and sectorial concentration limits the scope of employment generation and balanced regional development. The role of Indian SEZs in the foreign trade of the nation has been considerable by contributing a substantial share in overall export of the country. But there were different arguments in support and against the privileges given to SEZs by both Central and State Governments from different quarters. Now the government is in a mood to reduce the exemptions to SEZs. On the other hand Export Promotion Council for Export Oriented Units and Special Economic Zones (EPCES) has opposed the proposal being considered by the finance ministry for abolition of all direct tax benefits for SEZs not operationalized before April 2017. If the government moves forward with this idea it would certainly create uncertainty in the minds of investors, SEZ developers and units, and it will lead to an increase in the number of applications for de-notification of approved SEZs. In addition to the above challenge, maintaining the attractiveness of the SEZ policy after imposition of MAT and DDT on SEZ units and developers, evident lack of pro-business stance of thes government, lack of clarity about implication of proposed Goods and Services Tax (GST) on SEZs, issues relating to effectiveness of the Single Window Mechanism and lack of coordination across departments at the Central and State Government level, government proposal to introduce sunset clause on the benefits to SEZs affect its progress largely. Since it is contributing a lot for India's export, there is a need to rethink about the sectors to which the benefits need to be continued or to be restrained. Majority of the SEZs focus on high value added sectors like IT and ITEs, Pharma, Chemical, electronics, etc. The Government of India should focus on manufacturing sectors to establish their units within SEZs. The flagship scheme "Make in India" may be used as an opportunity in favour of SEZs in terms of investment, export promotion and employment generation.

\section{REFERENCES}

[1] Annual Reports: Department of Commerce, Ministry of Commerce and Industry, Government of India.

[2] Aradhana Aggarwal, SEZ-led Growth in Taiwan, Korea, and India: implementing a successful strategy, University of
California Press, Asian Survey, Vol. 52, No. 5, pp. 872-899, 2012.

[3] Aradhna Aggarwal, Impact of Special Economic Zones on Employment, Poverty and Human Development, Indian Council for Research on International Economic Relations: working paper 194, 2007.

[4] Aradhna Aggarwal, Special Economic Zones: Revisiting the Policy Debate, Economic \& Political Weekly, Vol. XLI, No. 43-44, 2006.

[5] Aradhna Aggarwal, Export Processing Zones in India: Analysis of the export performance, Indian Council for Research on International Economic Relations: working paper 148, 2004.

[6] Business Standard, Withdrawal of SEZ tax sops to hit exports, jobs: Trade Policy, $8^{\text {th }}$ December 2015.

[7] Deepak Shah, Special Economic Zones in India: A review of Investment, Trade, Employment generation and impact assessment, Indian Journal of Agricultural Economics, Vol.64, No.3, 2009.

[8] Deepashikha Sikarwar, "Modi govet's fresh approach: SEZs set to lose tax incentives in rationalization, The Economic Times, $10^{\text {th }}$ October 2015.

[9] EY's Attractiveness Survey India, Ready, Set and Grow, 2015.

[10] Ishan Bakshi, Why SEZs in India has failed, Business Standard, $4^{\text {th }}$ December 2014.

[11] Kirtika Suneja Commerce Ministry plans cut in tariffs, MAT on SEZ units, The Economic Times, $7^{\text {th }}$ October 2015.

[12] Naresh Kumar Sharma, Special Economic Zones: Socio Economic Implications, Economic \& Political Weekly, Vol. XLIV, No. 20, 2009.

[13] Notification, Department of Commerce, Ministry of Commerce and Industry, Government of India, $12^{\text {th }}$ August 2013.

[14] Pravakar Sahoo, Time to review the Special Economic Zones Act, Economic \& Political Weekly, Vol. L, NO. 14, $4^{\text {th }}$ April 2015.

[15] Statement of revenue forgone, Ministry of Finance, Government of India

[16] The Economic Times, Over 90 per cent SEZ's land lying vacant: Government, $7^{\text {th }}$ December 2015.

[17] The Economic Times, Tamil Nadu has maximum number of operational SEZs, $30^{\text {th }}$ November 2015.

[18] The Economic Times, Sunset clause for SEZs 'at odds' with Make in India: Dr Reddy's, $25^{\text {th }}$ November 2015.

[19] The Economic Times, Commerce Ministry Plans cut in tariffs, MAT on SEZ Units, $7^{\text {th }}$ October 2015.

[20] The Economic Times, SEZ developers seek exemption from MAT, $10^{\text {th }}$ September 2015.

[21] The Hindu, Government firming up measures to revitalize SEZs, $11^{\text {th }}$ December 2015.

[22] The Multi-Donor Investment Climate Advisory Service, Special Economic Zones: Performance, Lessons learned, and Implications for zones development, World Bank 2008. 